\title{
PENGARUH DATARAN TINGGI TERHADAP TINGKAT KEBUGARAN JASMANI MAHASISWA UNIVERSITAS NEGERI MANADO
}

\author{
Nurkadri \\ Universitas Negeri Medan, email : nurkadri@unimed,ac,id \\ Rizka Hayati \\ Universitas Negeri Medan, email : rizkahayati58@gmail.com
}

\begin{abstract}
Abstrak
Penelitian ini bertujuan untuk mengetahui tingkat kebugaran jasmani pada mahasiswa pendidikan kepelatihan olahraga Universitas Negeri Manado. Metode penelitian yang digunakan adalah deskriptif. Ukuran sampel menggunakan sistematic random sampling, sebanyak 30 Mahasiswa. Analisis data yang digunakan adalah analisis deskrptif dengan prosentase. Berdasarkan hasil penelitian yang dilakukan menunjukkan tingkat kebugaran jasmani mahasiswa dalam tiga kategori yaitu kategori baik 14 mahasiswa (46,67\%), kategori sedang yaitu 9 mahasiswa (30\%) serta serta kategori kurang yaitu 7 mahasiswa (23,33\%). Dapat ditarik kesimpulan bahwa mahasiswa FIK Universitas Negeri Manado memiliki kebugaran jasmani yang baik.
\end{abstract}

Kata Kunci: Kebugaran jasmani, dataran tinggi.

\begin{abstract}
This research aims to know the level of physical fitness in Sports Coaching Education Students at Manado State University. This research used descriptive method. The sample size uses systematic random sampling with 30 students. Analysis of the data used is descriptive analysis with percentages. Based on the results of research conducted at the level of physical students in three categories, they are, 14 students in good categories (46.67\%), 9 students of medium categories (30\%) and also the less category of 7 students (23.33\%). It can be concluded that the students of FIK Manado State University have good physical fitness.
\end{abstract}

Keywords: physical fitness, plateau.

\section{PENDAHULUAN}

Olahraga merupakan satu hal yang penting di masyarakat, yang merupakan integral dalam pembinaan dan pengembangan olahraga yang arahnya lebih pada kebugaran jasmani, mental dan rohani serta pembentukan kepribadian bermasyaraka(Hardiyono,NurkadrPratama, \& Laksana, 2019);. Berolahraga selama ini dilakukan hanya dengan berpedoman pada tanda-tanda perubahan yang muncul dan dihasilkan oleh tubuh. Faktor lingkunganjuga terhadap kondisi tubuh saat melakukan aktifitas olahraga. CORP ini menyajikan alasan untuk penggabungan tes tingkat kerja konstan kedua yang dilakukan pada $10110 \%$ dari tingkat kerja yang dicapai pada uji ramp awal untuk menyelesaikan dataran tingkat kerja Vo2-klasik yang merupakan validasi Vo2 max yang jelas. Utilitas yang luas dari prosedur ini telah ditetapkan untuk anak-anak, orang dewasa dari berbagai kebugaran, individu yang gemuk, dan populasi pasien. tes latihan kardiopulmoner; latihan tambahan; latihan beban konstan; transportasi oksigen; penyakit kardiorespirasi (Poole \& Jones, 2017).

Semakin ke atas tempat tinggal yang semakin jauh dari permukaan laut, kadar 
oksigen di udara atmosfer akan semakin rendah, selain itu temperatur udara daerah pegunungan termasuk ke dalam kategori normal tetapi memiliki tingkat kelembaban yang cukup tinggi berbeda dengan di dataran rendah yang memiliki suhu yang lebih panas dan kelembaban yang rendah. sehingga dengan kondisi alam yang demikian akan berpengaruh terhadap aktivitas fisik yang dilakukan. Kadar oksigen yang lebih rendah menyebabkan kadar hemoglobin lebih tinggi sehingga tubuh dapat menyesuaikan diri dengan keadaan alam.

Dengan perhitungan yang sangat mungkin individu seharusnya memiliki kesegaran jasmani yang baik dan suhu lingkungan yang mendorong untuk lebih bersemangat dalam berolahraga karena faktor lingkungan yang mendukung. Disini peneliti akan melakukan penelitian sejauh mana tingkat kebugaran jasmani mahasiswa pendidikan kepelatihan olahraga Universitas Negeri Manado dan seberapa besar tanggapan mereka tentang berolahraga dilingkungan masyarakat dataran tinggi. Secara umum kegiatan kebugaran fisik yaitu: sehat, di mana tubuh berada suatu kondisi yang bebas dari semua penyakit. Dimana tubuh mampu melakukan berbagai optimal setiap hari kegiatan tanpa kelelahan yang berlebihan dan masih memiliki cadangan energi.Kebugaran jasmani yang berhubungan dengan kesehatan yang berisi berbagai bentuk latihan gerak dan bentuk aktivitas daya tahan kardiorespirasi, kekuatan dan daya tahan otot dan fleksibilitas (Nurkadri, Valianto, \& Novita, 2019). selanjutnya (Proper et al., 2003); (Pate RR, et al., 1995); (Kesaniemi YK et al., 2001); (U.S. Department of Health and Human Services, 1996); (Caspersen CJ et al., 1994); (Pomerleau J et al., 2000) Hubungan positif aktifitas fisik dan kesehatan tidak lagi menjadi perdebatan saat ini. Orang yang aktif beraktifitas pada tingkat cukup sangat bermanfaat bagi kesehatan fisik dan mental dibandingkan orang yang tidak aktif. dinegara maju sebagian besar orang dewasa tidak aktif beraktifitas pada tingkat memuaskan, dalam hal ini sangatlah relevan untuk mensosialisasikan.

Ditempat kerja orang dewasa menghabiskan 8 jam sehari bekarja, mensosialisasikan aktivitas kebugaran di tempat kerja sangat efisien sebagai peningkatan aktifitas kebugaran bagi orang dewasa. pada dekade terakhir, program aktifitas kebugaran menjadi popular di kalangan orang dewasa dalam bekerja.Kebugaran jasmani adalah pencapaian aktifitas fisik yang dilakukan secara optimal, namun tetap dalam kondisi tubuh tidak mengalami kelelahan. kebugaran jasmani adalah suatu aspek fisik dan kebugaran menyeluruh (total fitness) yang dapat seseorang mampu untuk menjalankan kehidupan yang produktif dan dapat menyesuaikan pada tiap pembebanan atau stress fisik yang wajar (Sutarman, 2009). Kebugaran jasmani atau kesegaran jasmani adalah kemampuan seseorang untuk menunaikan tugas seharihari dengan mudah tanpa lelah yang berlebihan, serta masih memiliki cadangan tenaga untuk menikmati waktu senggang dan untuk keperluan mendadak (Sadoso Sumosardjono, 1986).

Kesegaran jasmani adalah kemampuan tubuh seseorang untuk melakukan tugas pekerjaan sehari-hari tanpa menimbulkan kelelahanyang berarti (EM Zul Fajri., Ratu Arilia Senja, 2008). Untuk dapat mencapai kondisi kesegaran jasmani yang prima seseorang perlu latihan yang melibatkan komponen kesegaran jasmani dengan metode yang benar (Depdiknas,2010). Kesegaran jasmani erat kaitannya dengan kegiatan manusia dalam melakukan pekerjaan \& bergerak, kesegaran jasmani yang dibutuhkan manusia dalam melakukan pekerjaan dan bergerak bagi setiap individu tidak sama. 
Kesegaran jasmani pada anak berbeda dengan kesegaran jasmani yang dimiliki orang dewasa bahkan tingkat kebutuhannya sangat individual (Afandi, 2009). Jadi Kesegaran jasmani merupakan sebuah keadaan atau kemampuan seseorang untuk melakukan aktivitas atau tugas-tugasnya sehari-hari dengan mudah tanpa mengalami kelelahan yang berarti

(Powers \& Howley, 1995). Suhu lingkungan ialah tingkatan derajat panas atau dingin yang berlaku dalam ruang sekitar. Suhu ini dapat diukur dengan menggunakan alat thermometer. Suhu lingkungan erat kaitannya dengan tingkat kelembaban udara. Semkain tinggi suhu lingkungan maka semakin tinggi pula tingkat kelembaban udara di sekitar. Suhu lingkungan dan kelembaban relative udara merupakan hal terpenting yang mempengaruhi penampilan dalam olahraga sehingga harus betul-betul diperhatikan (Giriwijoyo, (2007).

Cuaca dingin mempengaruhi penampilan fisik dalam berolahraga, walaupun pengaruhnya lebih kecil dibandingkan dengan cuaca panas. Walaupun demikian tetap juga beresiko, apalagi kompetisi dilakukan dalam cuaca yang sangat dingin, sehingga pengetahuan terhadap respon tubuh perlu diketahui dan harus berlatih dalam cuaca dingin agar aman dan berhasil (Pate dkk, 1993).Berdasarkan uraian tersebut maka peneliti mengambil kesimpulan untuk membuktikan dengan mengadakan penelitian dengan judul Pengaruh Dataran Tinggi Terhadap Tingkat Kebugaran Jasmani Mahasiswa Universitas Negeri Manado.

\section{METODE}

Metode penelitian merupakan cara yang digunakan untuk mengumpulkan data penelitian (Arikunto, 2005:97). Metode yang digunakan adalah deskriptif kualitatif untuk mendeskripsikan kebugaran jasmani dengan tes Lari 2.400 meter. Sedangkan dan masih mempunya isi atau cadangan tenaga untuk menikmati waktu senggangnya untuk keperluan-keperluan lainnya.

Lingkungan merupakan faktor penting yang harus diperhatikan dalam berolahraga. Lingkungan ini menyangkut: suhu lingkungan, kelembaban relatif udara, ketinggian tempat, dan lain-

rancangan penelitian adalah One-Shot yaitu model rancangan yang menggunakan satu kali pengambilan data pada suatu saat (Arikunto, 2006:81). Teknik pengambilan sampel menggunakan sistematic random sampling (Sugiyono, 2013:81). Instrumen penelitian yang digunakan dalam penelitian ini adalah Tes Kebugaran Jasmani Indonesia (TKJ). Tehnik pengumpulan data menggunakan metode tes, yaitu tes perbuatan. Penelitian ini bertujuan untuk mengetahui tingkat kebugaran jasmani mahasiswa Universitas Negeri Manado. Penelitian dilakukan di Stadion Universitas Negeri Manado. Populasi adalah mahasiswa angkatan 2019 Fakultas IImu Keolahragaan jurusan Pendidikan Kepelatihan Olahraga yang secara keseluruhan 60 orang, dan jumlah sample penelitian ini berjumlah 30 orang. Tahap pelaksanaan (Menjelaskan tentang cara pelaksanaan tes kesegaran jasmani kepada seluruh subyek penelitian dan Melakukan tes kesegaran jasmani Lari cepat 60 meter, Angkat tubuh 30 detik, Baring duduk 30 detik, Loncat tegak dan Lari 600 meter. Tehnik analisis data menggunakan analisis deskriptif dengan persentase (\%). Data yang diperoleh diberi skor sesuai dengan petunjuk penskoran yang sudah ada, selanjutnya skor dari ke 5 item tes dijumlahkan untuk mengetahui bagaimana tingkat kesegaran.

\section{HASIL DAN PEMBAHASAN Hasil}

Berdasarkan hasil penelitian, diperoleh tingkat kesegaran jasmani 
mahasiswa dari tes battery tes yaitu disajikan dalam bentuk table.

Tabel 1. Data hasil tes tingkat kebugaran jasmani mahasiswa Universitas

Negeri Manado

\begin{tabular}{|c|c|c|c|c|c|c|c|}
\hline No & $\begin{array}{c}\text { Skor } \\
\text { lari } \\
60 \\
\text { met } \\
\text { er }\end{array}$ & $\begin{array}{c}\text { Lomp } \\
\text { at } \\
\text { jauh } \\
\text { tanpa } \\
\text { awala } \\
\text { n }\end{array}$ & $\begin{array}{c}\text { Gantu } \\
\text { ng } \\
\text { siku } \\
\text { tekuk }\end{array}$ & $\begin{array}{c}\text { Lari } \\
\text { bola } \\
k \\
\text { balik } \\
4 \times 10 \\
\mathrm{~m}\end{array}$ & $\begin{array}{c}\text { (sit } \\
\text { up } \\
\text { ) } \\
30 \\
\text { de } \\
\text { tik }\end{array}$ & $\begin{array}{c}\text { Lo } \\
\text { nc } \\
\text { at } \\
\text { te } \\
\text { ga } \\
k\end{array}$ & $\begin{array}{c}\text { Lari } \\
600 \\
\text { met } \\
\text { er }\end{array}$ \\
\hline 1 & 10,8 & 153 & 28,9 & 15,1 & $\begin{array}{l}2 \\
3 \\
\end{array}$ & 8,0 & $\begin{array}{c}3.44 \\
, 5\end{array}$ \\
\hline 2 & 11,1 & 143 & 11,9 & 12,8 & 25 & 6,0 & $\begin{array}{c}2.36 \\
, 1 \\
\end{array}$ \\
\hline 3 & 10,5 & 158 & 19,0 & 12,5 & 23 & 5,5 & $\begin{array}{c}2.57 \\
, 9 \\
\end{array}$ \\
\hline 4 & 11,3 & 151 & 6,2 & 13,8 & 18 & $\begin{array}{c}13, \\
0\end{array}$ & $\begin{array}{c}2.18 \\
, 8 \\
\end{array}$ \\
\hline 5 & 14,2 & 79 & 2,5 & 14,5 & 5 & 9,5 & $\begin{array}{c}3.21 \\
, 1 \\
\end{array}$ \\
\hline 6 & 12,3 & 92 & 11,9 & 13,8 & 2 & $\begin{array}{c}11 \\
0\end{array}$ & $\begin{array}{c}3.36 \\
, 3 \\
\end{array}$ \\
\hline 7 & 11,5 & 138 & 20,7 & 14,4 & 20 & $\begin{array}{c}12, \\
0\end{array}$ & $\begin{array}{c}2.13 \\
, 5 \\
\end{array}$ \\
\hline 8 & 11,9 & 136 & 17,7 & 12,1 & 15 & 5,5 & $\begin{array}{c}3.05 \\
, 9 \\
\end{array}$ \\
\hline 9 & 14,2 & 105 & 2,3 & 13,8 & 9 & 7,5 & $\begin{array}{c}2.15 \\
, 9 \\
\end{array}$ \\
\hline 10 & 9,8 & 137 & 11,6 & 11,7 & 16 & 3,0 & $\begin{array}{c}2.26 \\
, 3 \\
\end{array}$ \\
\hline 11 & 10,6 & 128 & 27,1 & 11,3 & 15 & $\begin{array}{c}12 \\
5 \\
\end{array}$ & $\begin{array}{c}3.12 \\
, 3 \\
\end{array}$ \\
\hline 12 & 11,1 & 137 & 28,9 & 11,5 & 13 & $\begin{array}{c}10, \\
5 \\
\end{array}$ & $\begin{array}{c}2.23 \\
, 1 \\
\end{array}$ \\
\hline 13 & 9,8 & 125 & 20,7 & 11,6 & 14 & $\begin{array}{c}11, \\
0 \\
\end{array}$ & $\begin{array}{c}2.15 \\
, 7 \\
\end{array}$ \\
\hline 14 & 9,5 & 137 & 16,2 & 11,2 & 7 & 6,5 & $\begin{array}{c}2.23 \\
, 1 \\
\end{array}$ \\
\hline 15 & 16,3 & 112 & 3,9 & 14,5 & 14 & 8,0 & $\begin{array}{c}2.47 \\
, 8 \\
\end{array}$ \\
\hline 16 & 10,0 & 137 & 16,6 & 10,9 & 12 & 9,5 & $\begin{array}{c}2.02 \\
, 3 \\
\end{array}$ \\
\hline 17 & 11,5 & 112 & 11,5 & 10,7 & 12 & 9,5 & $\begin{array}{c}3,56 \\
, 0 \\
\end{array}$ \\
\hline 18 & 9,4 & 112 & 23,5 & 10,7 & 14 & $\begin{array}{c}12 \\
0\end{array}$ & $\begin{array}{c}2.52 \\
, 3 \\
\end{array}$ \\
\hline 19 & 10,2 & 153 & 11,8 & 11,4 & 18 & $\begin{array}{c}14, \\
5 \\
\end{array}$ & $\begin{array}{c}3.52 \\
, 3 \\
\end{array}$ \\
\hline 20 & 10,7 & 148 & 22,3 & 13,9 & 16 & $\begin{array}{c}13, \\
0\end{array}$ & $\begin{array}{c}2.55 \\
, 9 \\
\end{array}$ \\
\hline
\end{tabular}

\begin{tabular}{c|c|c|c|c|c|c|c}
\hline 21 & 14,4 & 96 & 5,2 & 12,2 & 12 & 9,5 & $\begin{array}{c}2.43 \\
, 2\end{array}$ \\
\hline 22 & 10,1 & 122 & 15,7 & 12,0 & 15 & $\begin{array}{c}12, \\
0\end{array}$ & $\begin{array}{c}2.16 \\
, 9\end{array}$ \\
\hline 23 & 16,6 & 86 & 7,4 & 12,1 & 3 & 4,0 & $\begin{array}{c}2.55 \\
, 7\end{array}$ \\
\hline 24 & 11,1 & 151 & 9,6 & 12,1 & 14 & $\begin{array}{c}12, \\
0\end{array}$ & $\begin{array}{c}2.43 \\
, 3\end{array}$ \\
\hline 25 & 9,6 & 137 & 19,4 & 12,2 & 23 & $\begin{array}{c}19, \\
4\end{array}$ & $\begin{array}{c}2,19 \\
, 8\end{array}$ \\
\hline 26 & 15,3 & 81 & 11,7 & 12,4 & 11 & 9,0 & $\begin{array}{c}2.58 \\
, 7\end{array}$ \\
\hline 27 & 10,2 & 118 & 17,5 & 10,5 & 8 & 7,0 & $\begin{array}{c}2.52 \\
, 3\end{array}$ \\
\hline 28 & 9,5 & 130 & 19,4 & 9,8 & 15 & $\begin{array}{c}12, \\
0\end{array}$ & $\begin{array}{c}2.52 \\
, 3\end{array}$ \\
\hline 29 & 10,9 & 142 & 28,9 & 10,7 & 14 & $\begin{array}{c}12, \\
2.46 \\
0\end{array}$ & $\begin{array}{c}2.46 \\
, 5\end{array}$ \\
\hline 30 & 9,7 & 139 & 7,4 & 11,4 & 9 & 7,5 & 2.59 \\
& & & & & & &, 7 \\
\hline
\end{tabular}

Setelah data pengukuran diketahui maka langkah selanjutnya adalah mencari nilai $\mathrm{T}$ table dengan melihat nilai yang diperoleh oleh masing masing mahasiswa untuk ketujuh tes tersebut.

Table 2. Jumlah nilai -T dan penggolongan tingkat kebugaran jasmani mahasiswa FIK universitas negeri manado

\begin{tabular}{c|c|c}
\hline No & $\begin{array}{c}\text { Jumlah nilai } \\
-\mathbf{T}\end{array}$ & $\begin{array}{c}\text { Penggolongan tingkat } \\
\text { kebugaran jasmani }\end{array}$ \\
\hline 1 & 374 & Sedang \\
\hline 2 & 388 & Baik \\
\hline 3 & 394 & Baik \\
\hline 4 & 385 & Sedang \\
\hline 5 & 286 & Kurang \\
\hline 6 & 312 & Kurang \\
\hline 7 & 391 & Baik \\
\hline 8 & 365 & Sedang \\
\hline 9 & 318 & Kurang \\
\hline 10 & 393 & Baik \\
\hline 11 & 375 & Sedang \\
\hline 12 & 395 & Baik \\
\hline 13 & 391 & Baik \\
\hline 14 & 390 & Baik \\
\hline 15 & 303 & Kurang \\
\hline 16 & 396 & Baik \\
\hline 17 & 345 & Sedang \\
\hline 18 & 390 & Baik \\
\hline 19 & 397 & Baik \\
\hline 20 & 369 & Sedang \\
\hline 21 & 299 & Kurang \\
\hline
\end{tabular}




\begin{tabular}{l|l|c}
\hline 22 & 393 & Baik \\
\hline 23 & 298 & Kurang \\
\hline 24 & 367 & Sedang \\
\hline 25 & 406 & Baik \\
\hline 26 & 293 & Kurang \\
\hline 27 & 375 & Sedang \\
\hline 28 & 400 & Baik \\
\hline 29 & 403 & Baik \\
\hline 30 & 369 & Sedang \\
\hline
\end{tabular}

Berdasarkan hasil penelitian yang dilakukan pada mahasiswa univeritas negeri manado menunjukkan bahwa tingkat kebugaran jasmani mahasiswa tersebar dlam tiga kategori baik 14, kategori sedang 9, kategori kurang 7 .

Tebel 3. Klasifikasi tingkat kebugaran jasmani mahasiswa Universitas Negeri Manado

\begin{tabular}{l|c|c}
\hline $\begin{array}{c}\text { Tingkat } \\
\text { kebugaran } \\
\text { jasmani }\end{array}$ & Jumlah & Presentase \% \\
\hline Baik & 14 & $46,67 \%$ \\
\hline Sedang & 9 & $30 \%$ \\
\hline Kurang & 7 & $23,33 \%$ \\
\hline
\end{tabular}

\section{Pembahasan}

Metode yang digunakan dalam penelitian ini adalah deskriptif bertujuan menggambarkan tingkat keburan jasmani mahasiswa universitas negeri manado . instrumen yang digunakan dalam penelitian ini adalah tes kebugaran jasmani indonesia (TKJI). teknik pengambilan data dalam penelitian ini yaitu dengan menggunakan tes lari cepat 50 meter, lompat jauh tanpa awalan, bergantung siku tekuk, lari bolak balik 4×10 meter, tes sit up, kelenturan togok kedepan dan tes lari 600 meter.

Data hasil penelitin ini diperoleh dari pengetesan tingkat kebugaran jasmani mahasiswa universitas negeri manado dengan jumlah sample 30 orang.

Data hasil pengukuran tingkat kebugaran jasmani mahasiswa dengan menggunakan 7 item tes yang digunakan dijadikan sample dalam penelitian ini dikonsultasikan dengan nikai $T$, dan nilai - $T$ dari keseluruhan tes tesebut dijumlahkan sehingga diperoleh hasil kebugaran jasmani berdasarkan norma. Tingkat kebugaran jasmani mahasiswa negeri manado diperoleh hasil dengan menggunakan tes lari cepat 50 meter, lompat jauh tanpa awalan, bergantung siku tekuk, lari bolak balik $4 \times 10$ meter, tes sit up, kelenturan togok kedepan dan tes lari 600 meter yang dijadikan sample dalam penelitian dikonsultasikan dengan nilai - $T$, dan nilai - $T$ dari keseluruhan tes tersebut dijumlahkan sehingga diperoleh hasil kebugaran jasmani mahasiswa berdasarkan norma tes kebugaran jasmani.

Berdasarkan hasil penelitian yang dilakukan pada mahasiswa menunjukkan bahwa tingkat kebugaran jasmani mahasiswa tersebar dalam tiga kategori yaitu kategori baik 14 mahasiswa dengan presentase $46,67 \%$ dan kategori sedang yaitu 9 mahasiswa dengan presentase $30 \%$ serta serta kategori kurang yaitu 7 mahasiswa dengan dengan presentase $23,33 \%$.

\section{PENUTUP \\ Simpulan}

Berdasarkan hasil penelitian dapat disimpulkan bahwa: Rata rata mean tingkat kebugaran jasmani mahasiswa FIK Universitas Negeri Manado yaitu 363.33 standar deviasi yaitu 38.52 dan tingkat penyebaran data (varians) yaitu 1483.7904. selanjutnya mahasiswa FIK Universitas Negeri Manado memiliki kebugaran jasmani yang baik. Didataran tinggi, suhu lingkungan memiliki pengaruh dengan kondisi fisik dari individu Karena kadar hemoglobin yang terdapat di sel darah manusia lebih besar dan mampu banyak mengikat oksigen. Sehingga presentasi keinginan untuk berolahraga juga lebih besar dimiliki oleh masyarakat yang bertempat tinggal didataran tinggi. 


\section{DAFTAR PUSTAKA}

Afandi, B. (2009). Pengaruh $\mathrm{CO} 2$ (Karbondioksida) Murni Terhadap Pertumbuhan Mikroorganisme Pada Produk Minuman Fanta Di PT. CocaCola Bottling Indonesia Unit Medan. Universitas Sumatra Utara.

Arikunto, Suharsimi. (2013). Prosedur Penelitian Suatu Pendekatan Praktek. Jakarta: Rineka Cipta.

Caspersen CJ, Merritt RK, Stephens T. (2018).International physical activity patterns: a methodological perspective. In: Dishman RK, ed. Advances in Exercise Adherence. Champaign, IL: Human Kinetics, 1994:73-110.

Depdiknas. (2010). Tes Kesegaran Jasmani Indonesia (TKJI). Jakarta: Pusat Pengembangan Kualitas Jasmani.

EM Zul, Fajri dan Ratu Aprilia Senja, (2008). Kamus Lengkap Bahasa Indonesia, Edisi Revisi, Cet. 3, Semarang: Difa Publishers,

Giriwijoyo (2007)., IImu Kesehatan Olahraga. Untuk Kesehatan dan Untuk Prestasi Olahraga. FPOK UPI.

Hardiyono, B., Nurkadri, N., Pratama, B. A., \& Laksana, A. A. N. P. (2019). The effect of the dominant muscle strength and self confidence on the results climb of the rock climbing's athlete. Jurnal SPORTIF: Jurnal Penelitian Pembelajaran. https://doi.org/10.29407/js_unpgri.v $5 i 1.12857$.

Nurkadri, Valianto, B., \& Novita. (2019). Effectiveness of physical fitness model with game approach in improving physical fitness of students at gajah mada elementary school in medan. Journal of Physics: Conference Series. https://doi.org/10.1088/17426596/1387/1/012125

Poole, D. C., \& Jones, A. M. (2017). Measurement of the maximum oxygen uptake Vo2max: Vo2peak is no longer acceptable. Journal of Applied Physiology. https://doi.org/10.1152/japplphysiol. 01063.2016

Powers, S., \& Howley, E. (1995). Exercise Physiology: Theory and Application to Fitness and Performances. Medicine \& Science in Sports \& Exercise. https://doi.org/10.1249/00005768199503000-00027

Proper, K. I., Koning, M., Van der Beek, A. J., Hildebrandt, V. H., Bosscher, R. J., \& Van Mechelen, W. (2003). The effectiveness of worksite physical activity programs on physical activity, physical fitness, and health. Clinical Journal of Sport Medicine. https://doi.org/10.1097/00042752200303000-00008.

Soraya, I., \& Sugihartono, T. (2019). Pengaruh Latihan Skj 2018 Terhadap Peningkatan Kebugaran Jasmani Mahasiswa Putri Penjas Unib. Kinestetik, 3(2), 249-255.

Sugiyono. 2013. Metode Penelitian Kuantitatif Kualitatif dan $R$ \& D. Bandung : Alfabeta.

Sumosardjono Sadoso 1986. Sehat dan Bugar. Gramedia Pustaka Utama. Jakarta Superior Sebelas Maret University Press Surakarta.

Sutarman. (2009). Pengantar Teknologi Informasi. Jakarta: Penerbit Bumi Aksara. 